\title{
Hubungan antara Gaya Hidup Hedonis dengan Perilaku Konsumtif pada Remaja
}

\author{
Ranti Tri Anggraini ${ }^{1}$ E Fauzan Heru Santhoso ${ }^{2}$ \\ Fakultas Psikologi Universitas Gadjah Mada Yogyakarta
}

\begin{abstract}
This study aimed to know the relationship between hedonic lifestyle with consumptive behavior among adolescents. The hypothesis in this study there was a positive relationship between hedonic lifestyle with consumptive behavior among adolescents. The subjects of this study were 141 Psychology students who were 18-21 years old. The data were collected using the hedonic lifestyle and consumptive behavior scale.The data analysis of this study using Product Moment correlation technique. The result of this study showed that there was a positive correlation between hedonic lifestyle with consumer behavior of adolescence $\left(r_{x y}=0,595\right.$ dengan $p=0,000(p<0,05)$. Based on the result, the hypotesis in this study can be accepted
\end{abstract}

Keywords: adolescents; consumptive behavior; hedonic lifestyle

\begin{abstract}
Abstrak. Penelitian ini bertujuan untuk mengetahui hubungan antara gaya hidup hedonis dengan perilaku kosnsumtif pada remaja. Hipotesis dalam penelitian adalah terdapat hubungan positif antara gaya hidup hedonis dengan perilaku konsumtif pada remaja. Subjek dalam penelitian ini merupakan 141 mahasiswa Fakultas " $X$ " Universitas " $Y$ " yang berusia 18-21. Data diperoleh dengan menggunakan skala gaya hidup hedonis dan skala perilaku konsumtif. Analisis data dilakukan dengan menggunakan teknik korelasi product moment. Hasil penelitian menunjukkan bahwa terdapat adanya hubungan antara gaya hidup hedonis dengan perilaku konsumtif pada remaja $\left(r_{x y}=0,595\right.$ dengan $p=0,000(p<$ 0,05). Berdasarkan hasil tersebut, hipotesis dalam penelitian ini diterima.
\end{abstract}

Kata kunci: gaya hidup hedonis; perilaku konsumtif; remaja

Di era globalisasi sekarang ini, berbagai bidang seperti ekonomi, teknologi, industri dan lain-lain telah mengalami kemajuan yang sangat pesat. Adanya kemajuan ini tentunya akan memudahkan masyarakat dalam melakukan sesuatu. Misalnya, di bidang ekonomi kini masyarakat tidak lagi kesulitan dalam mencari produk atau barang yang akan dibutuhkannya. Hal tersebut dikarenakan semakin tingginya tingkat produksi dan peredaran produk -

${ }^{1}$ Korespondensi mengenai isi artikel ini dapat dilakukan melalui ranti trianggraini@yahoo.com

2Atau melalui fauzan@ugm.ac.id barang dan jasa yang ditawarkan kepada masyarakat.

Banyaknya barang dan jasa yang ada di pasaran tentunya akan memengaruhi barang dan jasa yang ditawarkan kepada masyarakat. sikap individu terhadap pembelian dan pemakaian barang. Pembelian dan pemakaian suatu barang terkadang bukan lagi untuk memenuhi kebutuhan, melainkan didorong karena adanya faktor keinginan yang kurang berguna, seperti mengikuti trend, gengsi, menaikan prestise, dan berbagai alasan lainnya yang dianggap kurang penting. Sehingga hal tersebut secara langsung maupun tidak langsung menyebabkan 
daya beli dan sikap konsumtif meningkat (Anggarasari, 1997). Adanya keinginan untuk membeli suatu produk yang berlebihan merupakan awal munculnya perilaku konsumtif. Individu akan secara terus menerus membeli barang hanya berdasarkan apa yang mereka inginkan, bukan berdasarkan apa yang dibutuhkan (Fitriyani, Widodo, \& Fauziah, 2013).

Dewasa ini, perilaku konsumtif telah melanda semua kalangan masyarakat, salah satunya ialah kaum remaja. Menurut Santrock (2012) pada masa remaja, individu akan cenderung menyukai berbagai hal baru yang cukup menantang bagi dirinya, hal tersebut dikarenakan remaja berupaya untuk mencapai kemandirian dan menemukan identitas dirinya. Sementara itu, munculnya beberapa perubahan yang kemungkinan dialami oleh remaja baik perubahan fisik, sikap, perilaku, dan emosi. Salah satunya adalah perubahan perilaku yang cenderung konsumtif (Sukari, Larasati, Mudjijono, \& Susilantini, 2013).

Menurut Bush (Hylander, 2013) remaja merupakan salah satu kelompok yang sangat potensial bagi pemasar sebagai target pemasaran produk mereka, sehingga remaja tumbuh dalam budaya konsume-risme yang membuat remaja terlibat dalam perilaku konsumtif. Lebih lanjut, Mangkunegara (2005) mengungkapkan bahwa karakteristik remaja yang mudah terbujuk rayuan dan masih labil, impulsif dalam berbelanja kurang realistis dalam berpikir, serta cenderung berperilaku boros yang menjadikan remaja lebih konsumtif.

Sukari, et al. (2013) mengungkapkan bahwa kecenderungan remaja untuk berperilaku konsumtif dikarenakan semakin banyaknya sarana dan prasarana yang ada seperti pusat perbelanjaan atau mall, cafe, tempat makan atau restoran yang mengalami peningkatan. Remaja yang terjebak dalam kehidupan perilaku konsumtif seringkali menghabiskan uangnya hanya untuk membeli berbagai macam keperluan yang berdasarkan keinginannya bukan kebutuhan, seperti membeli handphone, pakaian, makanan, hiburan, dan lain-lain (Maulana, 2013). Hal ini senada dengan pendapat Solomon (1996) yang mengungkapkan bahwa sebagian besar uang remaja digunakan hanya untuk membeli produkproduk yang dapat memberikan kesenangan dan kepuasan pada diri mereka sendiri.

Yayasan Lembaga Konsumen Indonesia memberikan batasan mengenai perilaku konsumtif sebagai kecenderungan seseorang dalam mengkonsumsi tanpa memiliki batasan, serta lebih mengedepankan faktor keinginan daripada kebutuhan. Sumartono (2002) menyatakan bahwa perilaku konsumtif merupakan suatu tindakan yang dilakukan secara berlebihan terhadap penggunaan suatu produk. Lebih lanjut, perilaku konsumtif juga diartikan sebagai tindakan memakai suatu produk secara tidak tuntas. Artinya, seseorang membeli produk bukan karena produk yang dipakai telah habis, melainkan karena adanya iming-iming hadiah yang ditawarkan atau bahkan produk tersebut sedang trend (Sumartono, 2002). Pada penelitian ini terdapat lima aspek perilaku konsumtif, yaitu 1) pembelian impulsif (Lina \& Rosyid, 1997; Mangkunegara, 2005), 2) pemborosan (Lina \& Rosyid, 1997; Mangkunegara, 2005), 3) mudah terbujuk rayuan (Mangkunegara, 2005), 4) kepuasan (Solomon, 1996; Dharmmesta \& Handoko, 2014) dan 5) kesenangan (Solomon; 1996; Fransisca \& Suyasa, 2005).

Fenomena perilaku konsumtif ini tentunya akan terus berkembang, dikarenakan adanya faktor yang dapat menyebabkan munculnya perilaku konsumtif, salah satunya adalah gaya hidup. Menurut Chaney (Fransisca \& Suyasa, 2005) menyebutkan bahwa perilaku konsumtif 
terjadi karena timbulnya gaya hidup barat. Hadirnya pusat berbelanjaan yang menyajikan berbagai macam merek dari luar negeri. Kemudian, adanya restoran fast food yang seringkali membuat individu lebih memilih makanan barat daripada makanan dari produk lokal, serta adanya cafe-cafe yang cenderung digunakan oleh remaja sebagai tempat bersosialisasi dan nge-date. Kesadaran remaja yang tinggi akan terhadap produk-produk baru dan bermerk menyebabkan mereka cenderung untuk meniru gaya-gaya baru. Pola perilaku seperti ini diperkuat banyaknya majalah remaja, iklan, serta media lain yang secara langsung maupun tidak langsung untuk mengeksploitasi gaya hidup mewah dan mencolok (Lina \& Rosyid, 1997). Menurut Erikson, pada masa remaja individu harus memiliki gaya hidup sendiri yang khas dan dikenal sebagai dirinya walaupun mengalami berbagai macam perubahan (Gunarsa \& Gunarsa, 1983).

Dewasa ini, gaya hidup hedonis merupakan salah satu bentuk gaya hidup yang memiliki daya tarik bagi remaja. Dengan adanya fenomena tersebut, remaja cenderung untuk lebih memilih hidup yang mewah, enak, dan serba berkecukupan tanpa harus bekerja keras (Gushevinalti, 2010). Nadzir dan Ingarianti (2015) mengungkapkan bahwa gaya hidup hedonis merupakan suatu pola hidup seseorang yang melakukan aktivitasnya untuk mencari kesenangan hidup, menghabiskan waktunya di luar rumah untuk bersenang-senang dengan temannya, gemar membeli barang yang tidak dibutuhkan, serta selalu ingin menjadi pusat perhatian di lingkungan sekitarnya. Pada penelitian ini, aspek gaya hidup hedonis mengacu pada teori Reynold \& Darden (dalam Engel, Blackwell, \& Miniard, 1994) yaitu terdiri dari Aktivitas (activities), minat (interest), dan opini (opinion).
Menurut Kotler dan Amstrong (1994) bahwa gaya hidup merupakan salah satu faktor yang dapat mempengaruhi perilaku konsumtif. Gaya hidup seseorang akan menunjukkan pola kehidupannya yang dicerminkan melalui kegiatan, minat, dan opininya dalam berinteraksi di lingkungan di sekitarnya. Hawkins mengungkapkan bahwa gaya hidup yang dianut oleh seseorang akan berpengaruh terhadap kebutuhan, keinginan, serta perilakunya termasuk perilaku membeli (Yuniarti, 2015). Hal ini sejalan dengan hasil penelitian Hariyono (2015) menunjukkan bahwa gaya hidup memiliki hubungan positif dengan perilaku konsumtif pada remaja. Dalam penelitian tersebut, dijelaskan bahwa gaya hidup seseorang akan memengaruhi kebutuhan, keinginan dan perilaku membeli seseorang. Lebih lanjut, penelitian yang dilakukan oleh Febyanti (2006) pada remaja menunjukkan bahwa gaya hidup hedonis memiliki pengaruh positif terhadap perilaku konsumtif.

Penelitian ini bertujuan untuk mengetahui hubungan antara gaya hidup hedonis dengan perilaku konsumtif pada remaja. Hipotesis yang diajukan dalam penelitian adalah terdapat hubungan positif antara gaya hidup hedonis dengan perilaku konsumtif pada remaja. Semakin tinggi gaya hidup hedonis remaja maka semakin tinggi pula perilaku konsumtifnya. Begitu juga sebaliknya, semakin rendah gaya hidup hedonis remaja maka semakin rendah pula perilaku konsumtifnya.

\section{Metode}

Pada penelitian ini, terdapat dua variabel yaitu perilaku konsumtif sebagai variabel dependen, dan gaya hidup hedonis sebagai variabel independen. Penelitian ini dilakukan di Fakultas " $X$ " Universitas " $Y$ " pada tanggal 14-18 Mei 2018. Subjek dalam penelitian merupakan 141 mahasiswa 
Fakultas " $\mathrm{X}$ " Universitas " $\mathrm{Y}$ " yang berusia 18-21 tahun. Karakteristik subjek penelitian adalah berjenis kelamin laki-laki maupun perempuan, dan berusia 18-21 tahun. Pe- gaya hidup hedonis adalah sebesar 0,888. Validitas pada kedua istrumen penelitian ini menggunakan validitas isi yaitu melalui expert judgement.

Tabel 1

Deskripsi Data Penelitian

\begin{tabular}{ccccccccc}
\hline Variabel & \multicolumn{3}{c}{ Skor hipotetik } & \multicolumn{4}{c}{ Skor empirik } \\
\cline { 2 - 9 } & Min & Maks & Mean & SD & Min & Maks & Mean & SD \\
\hline Perilaku Konsumtif & 37 & 148 & 92,5 & 18,5 & 38 & 114 & 75,03 & 13,465 \\
Gaya Hidup Hedonis & 27 & 108 & 67,5 & 13,5 & 35 & 100 & 65,47 & 11,413 \\
\hline
\end{tabular}

milihan sampel pada penelitian ini dengan menggunakan teknik purposive sampling.

Instrumen yang digunakan dalam penelitian terdiri dari dua skala yaitu skala perilaku konsumtif untuk mengukur perilaku konsumtif, dan skala gaya hidup hedonis untuk mengukur gaya hidup hedonis. Skala perilaku konsumtif dikembangkan oleh Febyanti (2006) yang berdasarkan pada 5 Aspek perilaku konsumtif yaitu impulsif, pemborosan, kesenangan, kepuasan, serta mudah terbujuk rayuan dan pengaruh. Instrumen ini terdiri dari 37 aitem pernyataan, dan memiliki 4 alternatif jawaban yaitu SS= Sangat Sesuai. S=Sesuai, TS=Tidak Sesuai, dan STS=Sangat Tidak Sesuai. Skala perilaku konsumtif memiliki skor koefisien reliabilitas sebesar 0,901. Sementara itu, gaya hidup hedonis diukur dengan menggunakan skala gaya hidup hedonis yang juga dikembangkan oleh Febyanti (2006). Namun, pada instrumen ini dilakukan modifikasi skala yaitu dengan menambah sejumlah aitem pernyataan. Penyusunan instrumen ini berdasarkan 3 aspek yaitu aktivitas, minat, dan opini. Instrumen gaya hidup hedonis terdiri dari 27 aitem pernyataan dengan 4 alternatif jawaban yaitu SS= Sangat setuju, S=Setuju $\mathrm{TS}=$ Tidak Setuju, STS= Sangat Tidak Setuju. Skor koefisien reliabilitas skala
Uji hipotesis yang digunakan adalah analisis teknik korelasi Product Moment dari Karl Pearson dengan bantuan program Statistical Package for Social Science (SPSS) version 21.0 for windows.

\section{Hasil}

Subjek dalam penelitian ini berjumlah 141 responden yang terdiri dari 110 subjek berjenis kelamin perempuan, dan 31 subjek berjenis kelamin laki-laki. Apabila berdasarkan usia, diketahui bahwa sebagian besar subjek berusia 19 tahun yaitu sebanyak 66 responden. Sementara itu, data berdasarkan uang saku menunjukkan bahwa subjek yang memiliki uang saku sebesar Rp. 500.000 - Rp. 1.000 .000 paling banyak yaitu 34 responden, kemudian 33 responden dengan uang saku sebesar $>\mathrm{Rp}$. 2.000.000.

Pada penelitian ini, variabel perilaku konsumtif memperoleh hasil rerata skor empirik sebesar 75,03 lebih rendah dibandingkan dengan skor hipotetiknya yaitu sebesar 92,5. Sementara itu, pada variabel gaya hidup hedonis juga menunjukkan bahwa skor rerata empirik lebih rendah dari rerata skor hipotetiknya yaitu $65,47<67,5$. Tabel hasil deskripsi data penelitian disajikan pada tabel 1 . 
Berdasarkan tabel 1, menunjukkan bahwa terdapat perbedaaan skor empirik dan skor hipotetik. Skor mean hipotetik pada variabel perilaku konsumtif dan gaya hidup hedonis lebih besar daripada skor mean empirik, yang berarti kecenderungan perilaku konsumtif dan gaya hidup hedonis yang dimiliki subjek penelitian tergolong rendah. sebanyak 110 subjek (78\%). Pada kategori rendah terdapat 19 subjek $(13,5 \%)$, dan pada kategori tinggi terdapat 12 subjek $(8,5 \%)$.

Selanjutnya dilakukan uji normalitas Kolmogorov-Sminorv guna untuk mengetahui apakah data hasil penelitian terdistribusi normal atau tidak. Hasil uji normalitas menunjukkan bahwa pada

Tabel 2

Kategorisasi Data Penelitian Variabel Perilaku Konsumtif

\begin{tabular}{cccc}
\hline Norma Kategorisasi & Kategori & Jumlah & Persentase \\
\hline$X<74$ & Rendah & 65 & $46,1 \%$ \\
$74 \leq X<111$ & Sedang & 75 & $53,2 \%$ \\
$111 \leq X$ & Tinggi & 1 & $7 \%$ \\
\hline Total & & 141 & 100 \\
\hline
\end{tabular}

Tabel 3

Kategorisasi Data Penelitian Variabel Gaya Hidup Hedonis

\begin{tabular}{cccc}
\hline Norma Kategorisasi & Kategori & Jumlah & Persentase \\
\hline $\mathrm{X}<54$ & Rendah & 19 & $13,5 \%$ \\
$54 \leq \mathrm{X}<81$ & Sedang & 110 & $78 \%$ \\
$81 \leq \mathrm{X}$ & Tinggi & 12 & $8,5 \%$ \\
\hline Total & & 141 & $100 \%$ \\
\hline
\end{tabular}

Berdasarkan hasil di Tabel 2 menunjukkan bahwa sebagian besar perilaku konsumtif subjek penelitian berada pada kategori sedang yaitu sebanyak 75 subjek (53,2\%). Kemudian, sebanyak 65 subjek $(46,1 \%)$ termasuk dalam kategori rendah, dan hanya ada 1 subjek (7\%) berada pada kategori tinggi. Kemudian berda-sarkan hasil analisis data pada tabel 3, diketahui bahwa sebagian besar gaya hidup hedonis subjek penelitian berada pada kategori sedang yaitu terdapat variabel perilaku konsumtif memiliki skor keofisien Kolmogorov-Sminorv sebesar 0,502 dengan nilai signifikansi 0,963 ( $p$ $>0,05)$ yang artinya distribusi data normal. Sedangkan, pada variabel gaya hidup hedonis memiliki nilai skor koefisien Kolmogorov-Sminorv sebesar 0,935 dengan nilai signifikansi $0,346(p>0,05)$ yang berarti bahwa distribusi data normal. Dengan demikian, dapat disimpulkan bahwa kedua variabel penelitian ini telah memenuhi syarat uji normalitas. 
Tabel 4

Hasil Uji Hipotesis Korelasi Product Moment

\begin{tabular}{cccc}
\hline & Perilaku Konsumtif & $\begin{array}{c}\text { Gaya Hidup } \\
\text { Hedonis }\end{array}$ & Sig. (2-tailed) \\
\hline Pearson Correlation & 1 & 0,595 & 0,000 \\
\hline
\end{tabular}

Selain uji normalitas, dalam penelitian ini juga dilakukan uji linearitas dengan tujuan untuk mengetahui apakah variabel perilaku konsumtif dan gaya hidup hedonis linear atau tidak secara signifikan. Hasil uji linearitas menunjukkan nilai deviation from linearity sebesar 1,193 dengan nilai signifikansi $0,316(p>0,05)$, hasil tersebut menunjukkan bahwa terdapat hubungan yang linear antara gaya hidup hedonis dengan perilaku konsumtif.

Uji hipotesis pada penelitian ini adalah menggunakan teknik korelasi Product Moment untuk mengetahui hubungan antara gaya hidup hedonis dengan perilaku konsumtif. Tabel 4 menunjukkan hasil uji hipotesis korelasi Product Moment. Berdasarkan tabel tersebut, diketahui bahwa nilai $\mathrm{r}_{\mathrm{xy}} 0,595$ dengan $p=0,000(\mathrm{p}<$ $0,05)$. Dengan demikian, dapat disimpulkan bahwa terdapat hubungan positif antara gaya hidup hedonis dengan perilaku konsumtif. Sehingga, hipotesis yang diajukan dalam penelitian ini dapat diterima. Semakin tinggi gaya hidup hedonis, maka semakin tinggi pula perilaku konsumtifnya.

Penelitian ini juga dilakukan analisis tambahan guna untuk mengetahui perbedaan perilaku konsumtif antara laki-laki dan perempuan. Dengan menggunakan analisis $t$-test, diketahui bahwa nilai $\mathrm{t}$ hitung memiliki skor sebesar 0,378 dengan signifikansi sebesar 0,706. Hasil tersebut menunjukkan bahwa nilai signifikansi $\mathrm{p}>$ 0,05, sehingga dapat disimpulkan bahwa tidak terdapat perbedaan perilaku konsumtif yang signifikan antara subjek perempuan maupun laki-laki. Analisis tambahan selanjutnya adalah untuk melihat gambaran perilaku konsumtif berdasarkan uang saku bulanan. Analisis ini dilakukan dengan menggunakan uji one way Anova. Hasil uji Anova menunjukkan bahwa nilai $\mathrm{F}=3,488$ signifikansi perilaku konsumtif sebesar 0.010 ( $p<0.05)$, sehingga dapat dikatakan bahwa terdapat perbedaan perilaku konsumtif yang signifikan berdasarkan uang saku.

\section{Diskusi}

Penelitian ini bertujuan untuk mengetahui hubungan antara gaya hidup hedonis dengan perilaku konsumtif pada remaja. Hipotesis yang diajukan dalam penelitian adalah terdapat hubungan positif antara gaya hidup hedonis dengan perilaku konsumtif pada remaja. Berdasarkan hasil uji korelasi menunjukkan bahwa terdapat hubungan positif antara gaya hidup hedonis dengan perilaku konsumtif pada remaja. Semakin tinggi gaya hidup hedonis seseorang, maka semakin tinggi pula perilaku konsumtifnya. Begitu pun sebaliknya, semakin rendah gaya hidup hedonis seseorang, maka perilaku konsumtifnya juga semakin rendah. Dengan demikian, dapat disimpulkan bahwa hipotesis dalam penelitian ini diterima.

Hasil penelitian ini sejalan dengan hasil penelitian Febyanti (2006), dan Patricia dan Handayani (2014) yang menunjukkan bahwa gaya hidup hedonis berpengaruh positif terhadap perilaku konsumtif. Semakin tinggi gaya hidup hedonis seseorang maka semakin tinggi pula perilaku konsumtifnya. Begitu pun seba- 
liknya, semakin rendah gaya hidup hedonis seseorang, maka perilaku konsumtifnya juga semakin rendah.

Masa remaja merupakan masa di mana individu akan mengalami perubahan fisik, sikap, emosi, dan perilaku. Salah satunya adalah perubahan pada perilaku yang cenderung konsumtif (Sukari, et al., 2013). Menurut Sumartono (2002) munculnya perilaku konsumtif pada remaja disebabkan karakteristik psikologis remaja yang masih berada dalam proses pencarian jati diri, serta emosi remaja yang cenderung labil menyebabkan mereka mudah terkena pengaruh lingkungan. Parma (2007) menyatakan bahwa remaja selalu mengikuti keinginan mereka supaya terlihat fabulous atau cool, dan memotivasi mereka untuk memiliki sesuatu yang bukan keharusan sehingga menjadi lebih konsumtif.

Berdasarkan hasil penelitian diketahui bahwa sebanyak 53,2\% subjek memilliki perilaku konsumtif yang sedang, $46,1 \%$ subjek berperilaku konsumtif tergolong rendah, dan sebanyak $7 \%$ subjek tergolong dalam kategori tinggi. Dengan demikian, dapat dikatakan bahwa sebagian besar perilaku konsumtif pada subjek penelitian tergolong sedang. Hal tersebut menunjukkan bahwa subjek memiliki kendali yang cukup baik dalam menentukan perilaku konsumsinya. Hal ini juga didukung dengan karakteristik subjek yang berusia 18-21 tahun, di mana usia tersebut merupakan tahapan remaja akhir (Mönks, 2001). Menurut Hurlock (1980) individu yang berada pada masa remaja akhir sudah mulai mampu untuk mengambil keputusan secara matang, dan mampu menilai minatnya secara lebih kritis untuk mengetahui mana yang benar-benar penting. Dengan demikian, perilaku konsumsi mereka dalam membeli sesuatu harus dengan pertimbangan dan sesuai dengan kebutuhan mereka.
Tinggi atau rendahnya tingkat perilaku konsumtif individu tentunya dipengaruhi oleh berbagai macam faktor, salah satunya adalah gaya hidup. Hal ini senada dengan pendapat yang dikemukan oleh Hawkins et al. (1980) bahwa gaya hidup merupakan salah satu faktor yang seringkali dijadikan seseorang sebagai motivasi dasar dan pedoman dalam membeli sesuatu. Hasil penelitian Hariyono (2015) menunjukkan bahwa gaya hidup memiliki hubungan positif dengan perilaku konsumtif pada remaja. Dalam penelitian tersebut, dijelaskan bahwa gaya hidup seseorang akan memengaruhi kebutuhan, keinginan dan perilaku membeli seseorang.

Gaya hidup hedonis merupakan salah satu bentuk gaya hidup yang dikenal sebagai trend di kalangan remaja saat ini. Daya pikat gaya hidup hedonis tentunya sangat menarik bagi remaja sehingga munculah fenomena baru akibat adanya paham ini. Dengan adanya fenomena tersebut, remaja cenderung untuk lebih memilih hidup yang mewah, enak, dan serba berkecukupan tanpa harus bekerja keras (Gushevinalti, 2010).

Hasil penelitian ini menunjukkan bahwa sebanyak $78 \%$ subjek penelitian berada pada tingkat gaya hidup hedonis yang sedang. Menurut Mönks, et al., (2001) gaya hidup hedonis yang terjadi pada remaja dikarenakan adanya keinginan mereka agar penampilan, gaya tingkah laku, cara bersikap, dan lain-lain untuk menarik perhatian dari orang lain. Ditambahkan oleh Hurlock (1980) bahwa salah satu cara yang digunakan remaja untuk mengangkat diri-nya sebagai individu adalah dengan menggunakan simbol dan status melalui gaya hidupnya dalam bentuk mobil, pakaian, dan barang lainnya agar dapat dilihat orang lain.

Kunzmann, Stange, \& Jordan (2005) menyebutkan bahwa remaja dengan gaya 
hidup hedonis cenderung memiliki nilai seperti kenikmatan, harta benda, dan hiburan. Selain itu, individu tersebut seringkali terlibat dalam melakukan kegiatan sehari-hari yang menekankan pada kesenangan dan konsumsi. Hal ini sejalan dengan penelitian Sham, Shafi'e, dan Zahrin (2015) menunjukkan bahwa remaja dengan gaya hidup hedonis, modern, dan konsumtif cenderung membeli dan menggunakan barang-barang yang mahal, mewah, dan branded. Sementara itu, hasil penelitian Wahyudi (2013) menunjukkan bahwa remaja seringkali menghabiskan waktunya untuk berbelanja, jalan-jalan, atau hanya sekedar nongkrong di mall dengan alasan untuk memenuhi kepuasan diri dan kesenangan.

Hasil penelitian ini menunjukkan bahwa tidak terdapat perbedaan perilaku konsumtif perilaku konsumtif antara lakilaki dan perempuan. Hal ini sejalan dengan penelitian Rosadi (2014), dan Apriani (2017) yang menunjukkan tidak adanya perbedaan perilaku konsumtif antara laki-laki dan perempuan. Sementara itu, penelitian ini juga menemukan bahwa terdapat adanya perbedaan perilaku konsumtif berdasarkan uang saku. Banyak atau sedikitnya jumlah uang saku yang dimiliki kemungkinan akan memengaruhi perilaku konsumtifnya. Hasil ini sejalan dengan pendapat Kotler \& Amstrong (1994) yang menyatakan bahwa karakterisitik sosio ekonomi seseorang akan mempengaruhi cara perilaku konsumtif seseorang.

Penelitian ini tentunya masih memiliki keterbatasan antara lain yaitu jumlah subjek berdasarkan jenis kelamin belum tersebar secara merata, serta hasil penelitian ini tidak dapat digeneralisasi secara luas karena subjek pada penelitian ini hanya terbatas pada mahasiswa akultas " $X$ " Universitas " $Y$ ". Keterbatasan lainnya yaitu terletak pada alat ukur, terutama skala gaya hidup hedonis karena pilihan alternatif jawaban pada skala gaya hidup hedonis tidak dijelaskan pada petunjuk pengisian skala sehingga dapat menimbulkan persepsi yang berbeda pada subjek penelitian.

\section{Kesimpulan}

Berdasarkan hasil penelitian yang telah dilakukan dapat disimpulkan bahwa terdapat hubungan positif yang signifikan antara gaya hidup hedonis dengan perilaku konsumtif pada remaja. Semakin tinggi gaya hidup hedonis seseorang, maka semakin tinggi pula perilaku konsumtifnya. Begitu juga sebaliknya, semakin rendah gaya hidup hedonis seseorang, maka perilaku konsumtifnya semakin rendah.

\section{Saran}

Hasil penelitian menunjukkan bahwa gaya hidup hedonis merupakan salah satu faktor yang dapat mempengaruhi perilaku konsumtif pada remaja. Oleh karena itu, remaja disarankan untuk menghindari pola hidup yang berlebihan agar tidak terjerumus dalam perilaku konsumtif. Selain itu, remaja sebaiknya mampu mengendalikan dirinya sehingga terhindar dari dampak negatif perilaku konsumtif seperti pemborosan. Bagi peneliti selanjutnya yang ingin meneliti mengenai perilaku konsumtif, disarankan untuk mengkaji faktor lainnya yang dapat mempengaruhi perilaku seperti motivasi, kepribadian dan konsep diri, pengalaman, kebudayaan, kelas sosial, kelompok sosial, keluarga, dan lain-lain. Selain itu, peneliti selanjutnya disarankan untuk menambah jumlah subjek yang lebih banyak, serta memperluas cakupan subjek agar hasil penelitian dapat digeneralisasi. 


\section{Kepustakaan}

Anggarasari, R. E. (1997). Hubungan tingkat religiusitas dengan sikap konsumtif pada ibu rumah tangga. Psikologika, 2(4), 15-20. doi: $10.20885 /$ psikologika.vol2.iss4.art2

Apriani, P. A. (2017). Hubungan antara konsep diri dengan perilaku konsumtif mahasiswa terhadap produk fashion. (Skripsi tidak diterbitkan). Fakultas Psikologi Universitas Gadjah Mada, Yogyakarta.

Dharmmesta, B. S., \& Handoko, H. (2014). Manajemen pemasaran; analisis perilaku konsumen. Yogyakarta: Bpfe.

Engel, J. F., Blackwell, R. D., \& Miniard, P. W. (1994). Perilaku konsumen edisi keenam. Jakarta: Binarupa Aksara.

Febyanti, R. (2006). Perilaku konsumtif pada remaja ditinjau dari gaya hidup hedonis dan tipe kepribadian extravert introvert. (Tesis tidak diterbitkan). Fakultas Psikologi Universitas Gadjah Mada, Yogyakarta.

Fitriyani, N., Widodo, P. B., \& Fauziah, N. (2013). Hubungan antara konformitas dengan perilaku konsumtif pada mahasiswa di Genuk Indah Semarang. Jurnal Psikologi Undip, 12(1), 55-68. doi: 10.14710/ jpu.12.1.1-14

Fransisca, \& Suyasa, P. T. (2005). Perbandingan perilaku konsumtif berdasarkan metode pembayaran. Jurnal Phronesis, 7(2), 172-199.

Gunarsa, D, S., \& Gunarsa, Y. S. (1983). Psikologi perkembangan anak dan remaja. Jakarta: PT BPK Gunung Mulia.

Gushevinalti. (2010). Telaah kritis perspektif Jean Baudrilard pada perilaku hedonisme remaja. Jurnal Idea Fisipol UMB, 4(15), 45-59. doi: 10. 15575/psy.v3i2.1109

Hariyono, P. (2015). Hubungan gaya hidup dan konformitas dengan perilaku konsumtif pada remaja siswa
Sekolah Menengah Atas Negeri 5 Samarinda. eJournal Psikologi, 3(2),569578.

Hawkins, D. I., Coney, K. A., \& Best, R. J. (1980). Consumer behavior: Implications for marketing strategy. Ontario: Business Publications, Inc.

Hurlock, E. B. (1980). Psikologi perkembangan: Suatu pendekatan sepanjang rentang kehidupan. Jakarta: Erlangga.

Hylander, F. (2013). To think, to feel, to have: The effects of need for cognition, hedonism and materialism on impulse buying tendencies in adolescents. Journal of European Psychology Students, 4(2), 25-32. doi: 10.5334/jeps.bh

Kotler, P., \& Amstrong, G. (1994). Dasar dasar pemasaran. Jakarta: Intemedia Jakarta.

Kunzmann, U., Stange, A., \& Jordan, J. (2005). Positive affectivity and lifestyle in adulthood: do you do what you feel?. The Society for Personality and Social Psychology, 31(4), 574-588. doi: 10.1177/0146167204271586

Lina, \& Rosyid, H. F. (1997). Perilaku konsumtif berdasar locus of control pada remaja putri. Psikologika, 2(4), 513

Mangkunegara, A. P. (2005). Perilaku konsumen. Bandung: PT. Refika Aditama.

Maulana, R. (2013, Oktober 18). Remaja dan perilaku konsumtif. Diunduh dari Kompasiana.com:

https://www.kompasiana.com/maulan aridone/552a70ce6ea834ad6c552d01/re maja-dan-perilaku-konsumtif tanggal 27 Maret 2018.

Mönks, F. J., Knoers, A. M., \& Haditono, S. R. (2001). Psikologi perkembangan pengantar dalam berbagai bagiannya. Yogyakarta: Gadjah Mada University Press.

Nadzir, M., \& Ingarianti, T. M. (2015). Psychological meaning of money dengan 
gaya hidup hedonis remaja. Seminar Psikologi \& Kemanusiaan. 582-596. Malang: Psychology Forum Umm.

Parma, S. A. (2007). Hubungan antara konsep diri dengan perilaku konsumtif remaja putri dalam pembelian kosmetik melalui katalog. Skripsi, Fakultas Psikologi Universitas Diponogoro, Semarang.

Patricia, N. L., \& Handayani, S. (2014). Pengaruh gaya hidup hedonis terhadap perilaku konsumtif pada pramugari maskapai penerbangan " $X$ ". Jurnal Psikologi, 12(1), 10-17.

Rosandi, A. F. (2004). Perbedaan perilaku konsumtif antara mahasiswa laki-laki dan perempuan. Skripsi. Universitas Katolik Indonesia Atma Jaya.

Santrock, J. W. (2012). Life span development edisi ke-13. Jakarta: Erlangga.
Sham, F., Shafi'e, S. Z., \& Zahrin, S. N. (2015). Adolescent lifestyle in Malaysia. Mediterranean Journal of Social Sciences, 6(3), 271-276.

Solomon, M. R. (1996). Consumer behavior; buying, having, and being. United State: Prentice - Hall International, Inc.

Sukari, Larasati, A., Mudjijono, \& Susilantini, E. (2013). Perilaku konsumtif siswa SMA di Daerah Istimewa Yogyakarta. Yogyakarta: Balai Pelestarian Nilai Budaya (Bpnb).

Sumartono. (2002). Terperangkap dalam iklan. Bandung: Alfabeta.

Wahyudi. (2013). Tinjauan tentang perilaku konsumtif remaja. Ejournal Sosiologi, 1(4), 26-36.

Yuniarti, V. S. (2015). Perilaku konsumen teori dan praktik. Bandung: Pustaka Setia. 